\title{
PRINCIPLES OF SOCIAL COST-BENEFIT ANALYSIS OF PUBLIC ROAD PROJECTS FOLLOWED IN SOUTH AFRICA
}

\author{
W.J. Pienaar ${ }^{1 *}$
}

\section{ARTICLE INFO}

\section{Article details}

Submitted by authors 15 Feb 2018 Accepted for publication 19 Oct 2018 Available online $\quad 10 \mathrm{Dec} 2018$

\section{Contact details \\ * Corresponding author wpienaar@sun.ac.za \\ Author affiliations \\ 1 Department of Industrial Engineering, Stellenbosch University, South Africa}

DOI

http://dx.doi.org/10.7166/29-4-1926

\section{ABSTRACT}

This article discusses the most pertinent principles that underlie the preferred social cost-benefit analysis methodology to evaluate public road projects in South Africa. The 'cost' component of the analysis is the once-off investment cost sacrificed to establish a facility, and the 'benefit' component is the recurring reduction of disutility emanating from the operation, maintenance, and use of a facility. To determine future road-user benefits, the article develops a social surplus criterion that is termed 'socio-economic user surplus'. A procedure is provided of the way that social costbenefit analysis should be supplemented by the application of equity weighting, with a view to indicating both the expected allocative efficiency and distributive efficiency of a proposed road project. Lastly, the article discusses why the economic impacts that may stem from economically justified road projects are not considered in a social cost-benefit analysis.

\section{OPSOMMING}

In hierdie artikel word die mees tersaaklike beginsels bespreek wat die metodiek van sosiale kostevoordeelontleding om openbare padprojekte in Suid-Afrika te evalueer, onderlê. Die 'koste'komponent van die ontleding is die eenmalige investeringskoste wat opgeoffer word om 'n fasiliteit te vestig. Die 'voordeel'-komponent van die ontleding is die herhalende vermindering van buitewerkstelling wat uit die bedryf, instandhouding, en gebruik van 'n fasiliteit spruit. Wat toekomstige padgebruikersvoordele betref, ontwikkel die artikel 'n sosiale surplusmaatstaf genaamd 'sosio-ekonomiese gebruikersurplus'. 'n Prosedure word voorsien waarvolgens sosiale kostevoordeelontleding met billikheidsweging aangevul behoort te word, om sowel toewysingsdoeltreffendheid as verdelings-doeltreffendheid van ' $n$ voorgestelde pad projek te toon. Laastens bespreek die artikel waarom die ekonomiese impakte wat uit ekonomies geregverdigde padprojekte kan spruit nie in sosiale kostevoordeelontleding oorweging geniet nie.

\section{INTRODUCTION}

The purpose of this article is to discuss the most pertinent principles that underlie the socioeconomic evaluation methodology proposed to evaluate public road projects in South Africa. The proposed methodology aims to establish a standard set of requirements according to which a socioeconomic evaluation of urban and rural roads must be undertaken in a consistent manner. Emphasis is placed on those matters that are not dealt with in a consistent manner internationally, and by analysts in South Africa. Socio-economic evaluation, as discussed, includes both social cost-benefit analysis (SCBA), based on allocative efficiency, and social evaluation, based on distributive efficiency or equity. SCBA does not include financial evaluation. The article deals with matters of principle; methodological aspects are not discussed. 
The purpose of the SCBA of infrastructure projects is to inform the decision-maker in a standardised and systematic manner of the social costs and benefits of such projects. The need for this information arises because transport activities may impose costs and other forms of disutility on others not party to the transport activity. Examples are pollution caused by vehicles and public liability caused by accidents (such as pain, suffering, and loss of income). These social costs are usually excluded in private transport investment decision-making. It therefore falls on government entities to invest in public transport infrastructure, as they are the only bodies in a position to base decisions on maximising the benefit to society as a whole.

Whereas a socio-economic evaluation concerns the identification and measurement of the social opportunity costs of a project and the size and distribution of its benefits, a financial evaluation concerns the determination of the project's financial affordability and viability. In the case of a government-funded road project, a financial evaluation will aim to determine whether the initial capital expenditure and the recurring operational and maintenance expenditure it will require are affordable. In the case of a toll road, the facility operator will investigate whether the projected toll revenues will be adequate to defray its financial obligations arising from project implementation and operation, and realise an acceptable return on the capital invested. In a financial evaluation of a road project, the 'costs' are made up by the aggregate of the capital expenditure and the operational and maintenance expenditure of the road, and the 'benefits' by what users are willing to pay to use the road. External costs that arise because of the project are not taken into account in a financial evaluation, unless the government internalises external cost created in the transport process through levies that increase the prices of resources used.

The article is structured in six sections. The next (second) section is devoted to the identification of the 'cost' component within SCBA. The items that are included in the 'benefit' component of SCBA are explained in the third section. The fourth section outlines the need also to consider distributive efficiency as supplementary to allocative efficiency. The fifth section briefly discusses why economic impacts do not form part of an SCBA. The conclusions of the study appear in the last section.

\section{THE COST COMPONENT OF SOCIAL COST-BENEFIT ANALYSIS OF PUBLIC ROADS}

\subsection{Introduction}

The social opportunity cost of the investment needed to establish or implement a road facility is the cost of the factors of production sacrificed to establish the road facility. This includes the following cost items:

(a) Direct planning and design, such as traffic surveys, studies of use and establishing a facility, environmental impact studies, compilation and recording of the construction details, etc.;

(b) The land reserve and preparation of the site for development, including demolishing, levelling, reinforcement, etc.;

(c) The construction of the facility, including the construction of access links, installation of traffic control devices and other appurtenances, landscaping, and project management.

Each of the above-mentioned items includes the shadow price - i.e., the social opportunity cost for materials and equipment used, labour, contractor operating and overhead costs, and normal profit - in fact, the actual scarcity value of all inputs that are needed to create the facility and to link it to the existing road network and places to which it provides access (i.e., to supply it complete and ready for use).

\subsection{Shadow price of investment costs}

Existing components and past expenditure on planning, design, and other project development costs that have no alternative application value bear no opportunity cost. Their costs are regarded as sunk, and such historic expenditures are excluded from the analysis. All new constructions are assessed on the basis of present construction costs. Where present construction costs serve as a basis for these calculations, adjustments have to be made for indirect taxes, distorted labour prices, and prices of project resources distorted by market imperfections that serve as an input.

In developed countries, the labour market is often fairly unrestricted, and shadow pricing of the labour component of costs is seldom considered necessary. However, in developing countries such 
as South Africa and its neighbours, the market price for labour, especially unskilled labour, is usually a poor guide to the economic price because of minimum wage legislation and restrictive practices. A more reliable guide to the economic cost of labour can then be obtained by applying the opportunity-cost principle, based on its use in alternative revenue-earning opportunities. In times of high unemployment, this value for unskilled labour would be low, probably equal to the minimum living-level wage at which people will find it worthwhile to endure the disutility of working in favour of a subsistence wage. The practice has been to set the shadow wage equal to the average unemployment benefits received by the unemployed [1]. Where there is no unemployment, the market price of labour is used for all labourers [2].

The shadow wage of unskilled, semi-skilled, and skilled workers (excluding professionals and managers) should be based on the minimum living-level wage determined for the lowest-paid workers on these levels of skill in the area concerned. In general, it is unlikely that a lower shadow wage will apply, so that the possibility of overestimating the opportunity cost of the labour involved is small. Even under conditions of unemployment, the labour of professionals and managers must still be valued at market prices, as this labour category remains relatively scarce in South Africa in such conditions [2].

For the purpose of SCBA, unskilled labourers are regarded as those workers for whom literacy and numeracy are not required to conduct their work; semi-skilled and skilled workers are those persons for whom tertiary education is not a requirement for their work; and professionals and managers are those employees for whom appropriate or specified tertiary education is a requirement for their work.

\subsection{Analysis period and service life}

To adequately account for benefits realised, it is desirable that the analysis period should stretch over the entire service life of a facility. However, because of uncertainties, all forecasts are speculative and therefore doubtful, owing to the difficulty of predicting future traffic volumes, modal split, changes in technology, land use, the necessity to improve and change road geometric standards, etc. For this reason it is advisable that analysis periods not exceed 30 years, even though a road may contain durable indivisible components whose longevity exceeds 30 years. A further factor militating against analysis periods exceeding 30 years is that traffic growth might lead to road space demand volumes that exceed the present affordability of supplying substantial initial overcapacity of a road. For example, at an average growth of three per cent per annum, traffic volume will increase by a factor of almost 2.5 over 30 years.

As is the case with the treatment of residual road value during its service life, the terminal value at the end of a road's service life should be regarded as nil, because the road structure and other remnants cannot be expected to have any alternative application possibilities: first, the structure is a specialised road facility that excludes alternative non-transport-related use; and second, the costs of demolishing and removing retired structures and earthworks in order to rehabilitate the site for alternative land use might not be viable, leading to road sites generally simply being abandoned at the end of their service life.

\section{THE BENEFIT COMPONENT OF SOCIAL COST-BENEFIT ANALYSIS OF PUBLIC ROADS}

\subsection{Recurring cost savings}

The benefits of a road project are estimated using a 'with and without' comparison. Recurring costs are first projected for a continuation of the existing situation in which no expenditure will be incurred on improvements other than those related to ad hoc, routine, periodic, and emergency maintenance in order to keep the road usable by traffic. Recurring costs are then determined for the improved road, and the benefits determined as the saving in recurring costs resulting from the improvement.

Recurring costs on a road include (1) road-user costs; (2) external costs imposed on non-users; and

(3) road maintenance costs. The main components of road-user costs are:

(a) Vehicle operating costs, such as fuel consumption and vehicle maintenance; 
(b) Time costs of vehicle occupants (including all delays, counting those experienced during road maintenance);

(c) Accident costs (although accidents also have an external impact, all direct and indirect accident costs are treated as if they were road-user costs);

(d) Other road-user disutility experienced:

(i) Traffic unreliability (variability in travel times);

(ii) Parking costs;

(iii) Vehicle cargo (delay and damage) costs;

(iv) Personal insecurity.

External costs imposed on the community/non-users of a road include the following:

(a) Barrier impact of a road, resulting in a reduction in connectivity across the road;

(b) Urban sprawl, leading to longer travel distances and an efficiency loss in the supply of public transport;

(c) Noise impacts;

(d) Air, water, and soil pollution;

(e) Visual intrusion/unsightliness;

(f) Waste-disposal effects;

(g) Environmental impact, such as the loss or deterioration of existence value of natural serenity.

A road improvement could lead either to an increase (negative saving) or a decrease (positive saving) of some recurring cost components. Road maintenance, and probably external cost, will increase when (1) the new road is an addition to the existing network; (2) the new road replaces an old road, but is much more elaborate in size - for example, when more traffic lanes are added to a road, or a single carriageway is replaced by a dual one; and (3) there is an increase in traffic on a road. An example of obtaining a positive maintenance cost saving is by paving an unpaved road surface that suffers from the onslaught of severe and chronic rainy weather, with the result that its maintenance cost decreases.

\subsection{Principles underlying the determination of road-user benefits}

In an SCBA, the benefit of a road improvement to road users can be measured in terms of the increased user surplus, termed 'socio-economic user surplus' in this article. This surplus is the difference between what able users are willing to pay, expressed as a shadow price (indicated by a 'shadow demand curve'), and the price that the users actually pay to use a road, also expressed as a shadow price. The terms 'socio-economic user surplus', 'shadow demand curve', and 'shadow price' are not present in any discourse apart from their use in SCBA.

Until the mid-1970s, analysts generally believed that demand curves for usage of specific road sections indicated relationships between monetary travel costs and number of trips per period only, and that any road renewal that led to improved quality of travel would move the demand schedule to the right. This belief greatly hindered the estimation of a consumer's surplus.

Winfrey [3] was a prominent American transport analyst and prolific author in the field of highway economics who rejected attempts to estimate road-user surpluses. He stated: "The consumer surplus concept is rejected for two reasons. First, the economy of highway transportation on which to base a decision of economic feasibility should be based on market-priced changes in consumption of resources rather than the consumer surplus concept of value (willingness to pay). Second, in the analysis, net changes in consumer surplus for highway design and traffic improvements cannot be estimated because there are no price-demand curves."

In South Africa, the esteemed economist J de V Graaff [4] cast doubt on attempts to estimate road-user surpluses for use in SCBA by stating: "If enough information is available to build up a demand curve, some attempt will be made to add in a rough estimate of consumer's surplus. If a market price does not exist, because there is no market, great ingenuity will be brought to bear on the problem of calculating what it would have been if there were a market."

Over the past four decades, the sophistication of techniques to monetise intangibles through surrogate pricing, and to forecast travel demand analytically, have developed beyond recognition. The continuing quest to apply principled analysis has prompted the development of methodologies in which (1) techniques to price non-market and intangible features and (2) techniques to forecast stochastic 
transportation demand that take cognisance of cause-effect relationships were conceived. In the light of this, the article confines itself to a consideration of principles; these techniques are not discussed here.

During the mid-1970s, an idea taking root among transport-demand analysts was that the demand for transport was not a function of monetary travel costs alone, but rather of the general associated opportunity costs. To place a single composite value on these different intangibles, transport economists have developed the concept of 'generalised cost' [5]. Goodwin [6] argued: "The generalised cost of a trip is experienced as a single, usually monetary, measure combining, generally in linear form, most of the important but disparate costs which form the overall opportunity costs of the trip. On occasions a generalised time cost measure may replace the financial index." Based on this, Button [7] concludes: "The characteristic of generalised cost is, therefore, that it reduces all cost items to a single index and this index may then be used in the same way as monetary costs are in standard economic analysis." This view is shared by Sinha and Labi [8]: "In a bid to simplify a multi-attribute demand function, the ordinate could be expressed as a single cost variable that is an agglomeration of other trip or service attributes, such as trip fare, time, discomfort, safety and security, out-of-pocket expenses, and other 'sacrifices' that each traveller incurs in making a trip. Therefore the various costs incurred by the trip maker can collectively represent the user cost that will be incurred by the trip maker. ... Demand changes in such cases are represented by an upward and downward slide along the demand curve."

The concepts of consumer surplus and of socio-economic user surplus are illustrated in Figure 1 . This figure shows two demand curves: one as perceived and generalised by road users, and the other based on shadow prices. The perceived consumer surplus is the area PBD below the perceived demand curve and above the generalised cost $P$ that users are perceiving to be paying for transport. The socio-economic user surplus is the area UAC below the shadow demand curve and above the shadow price $U$ that users are paying for transport.

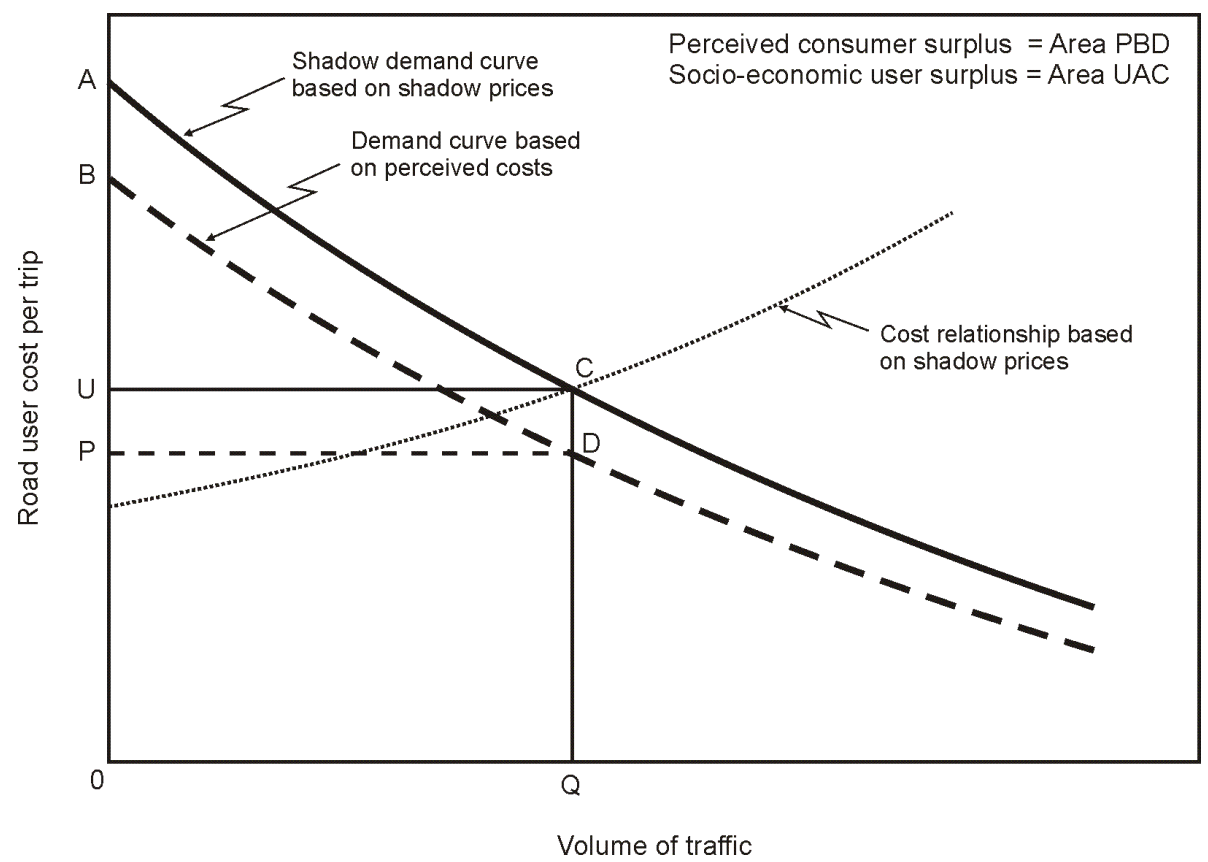

Figure 1: Perceived consumer and socio-economic user surplus

The generalised costs perceived by road users are normally lower than the socio-economic cost or shadow price of transport, since road users normally do not take the full cost of travel into account in their travel choices [9]. For example, road users do not typically take the full vehicle operating or accident costs into account. 
In order to establish the road-user benefits of a road project, it is necessary to differentiate between the various classes of traffic. The following three classes are used for this purpose: normal traffic, diverted traffic, and induced traffic. These traffic classes are defined as follows:

- $\quad$ Normal traffic:

- Existing traffic; current traffic on an existing road. When a new road is to be introduced without any changes to the existing road network in the area, the existing traffic is taken as zero. When a new road replaces an existing one, the current traffic of the existing road is taken as the existing traffic of the new road.

- Normal-growth traffic; traffic growth that would have occurred in spite of a road improvement project. The growth may be attributable to (a) general population growth; (b) an increase in the per capita ownership of vehicles; and (c) an increase in average use per vehicle.

- Non-induced development traffic; traffic that will be generated by specific land development(s) in tandem with a road's development in order for the land development(s) to be accessible from the outset. This traffic does not form part of induced development, but is in addition to normal growth traffic.

- $\quad$ Diverted traffic

- Traffic that is diverted from other roads or other modes of transport to a road as a result of road improvements. When a road is improved without any improvements to other roads or transport modes in the network, all the traffic attracted to the new or improved road is regarded as diverted traffic. Traffic diversion may also occur without an improvement as a result of increased congestion or costs on other roads or modes of transport in the network.

- Induced traffic:

- Induced traffic consists of induced development traffic and latent traffic. Whereas induced development traffic is attributable to improved accessibility, latent traffic is attributable to the easing of mobility. These two traffic components can be described as follows:

- Induced development traffic; increased traffic as a result of land developments stimulated by road improvements. The supply of new or improved road facilities in a developing region usually stimulates economic development and settlement as a result of greater accessibility. Improved access generally results in changed and more intensive land use, which, in turn, 'develops' more traffic in the corridor through which the road passes.

- Latent traffic; traffic that did not exist previously, and has been induced solely through a reduction of the disutility of travel, brought about by lower user costs and higher service quality offered by the improvement or provision of the road. Latent traffic consists of previously potential road users - i.e., formerly dormant road users who have been encouraged to join the traffic as a result of the reduction of the perceived generalised cost of travel to below the price they are willing to pay for travelling. This puts new destinations and travel opportunities within their reach.

The total amount of traffic travelling on an improved road during a year is the total traffic for each of the classes indicated in the formula:

$$
\mathbf{Q}_{\mathrm{t}}=\mathbf{Q}_{\mathrm{Nt}}+\mathbf{Q}_{\mathrm{DT}}+\mathbf{Q}_{\mathrm{IT}}
$$

in which:

$\mathrm{Q}_{\mathrm{t}} \quad=$ Total traffic on an improved road during year $\mathrm{t}$

$\mathrm{t}=\mathrm{A}$ year in the analysis period

$Q_{\mathrm{Nt}}=$ Total normal traffic during the year

$Q_{D t}=$ Total diverted traffic during the year

$\mathrm{Q}_{\mathrm{t}}=$ Total induced traffic during the year

\subsubsection{Benefits to normal traffic}

The benefit of a road improvement for normal traffic is the reduction in road-user cost, as given by the following formula: 


$$
\Delta \mathrm{U}_{\mathrm{Nt}}=\left(\mathrm{U}_{0 \mathrm{t}}-\mathrm{U}_{\mathrm{At}}\right) \cdot \mathrm{Q}_{\mathrm{Nt}}
$$

in which:

$\Delta \mathrm{U}_{\mathrm{Nt}}=$ Annual benefits to normal traffic in year $\mathrm{t}$

$\mathrm{U}_{0 \mathrm{t}}=$ Shadow price per trip for the existing road

$\mathrm{U}_{\mathrm{At}}=$ Shadow price per trip for the improved road

$\mathrm{Q}_{\mathrm{Nt}}=$ Annual normal traffic in year $\mathrm{t}$

\subsubsection{Benefits to diverted traffic}

Savings that road users obtain by switching from other roads to a new or improved road are given by the following formula:

$$
\Delta \mathrm{U}_{\mathrm{Dt}}=\left(\mathrm{U}_{\mathrm{d} 0 \mathrm{t}}-\mathrm{U}_{\mathrm{At}}\right) \cdot \mathrm{Q}_{\mathrm{Dt}}
$$

in which:

$\Delta \mathrm{U}_{\mathrm{Dt}}=$ Annual benefits to diverted traffic in year $\mathrm{t}$

$\mathrm{U}_{\mathrm{dot}}=$ Shadow price per trip on road(s) from which traffic was diverted

$\mathrm{U}_{\mathrm{At}}=$ Shadow price per trip for the improved road

$Q_{D t}=$ Annual diverted traffic in year $\mathrm{t}$

In addition to the above benefits to diverted traffic, the diversion is also beneficial for traffic that remains on the other road. These benefits can be determined as:

$$
\Delta \mathrm{U}_{\mathrm{dDt}}=\left(\mathrm{U}_{\mathrm{d} 0 \mathrm{t}}-\mathrm{U}_{\mathrm{dAt}}\right) \cdot \mathrm{Q}_{\mathrm{dAt}}
$$

in which:

$\Delta \mathrm{U}_{\mathrm{dDt}}=$ Benefits to traffic remaining on other road(s) in year $\mathrm{t}$

$\mathrm{U}_{\mathrm{dot}}=$ Shadow price per trip for the other road(s) without improvement

$\mathrm{U}_{\mathrm{dAt}}=$ Shadow price per trip for the other road(s) with improvement

$\mathrm{Q}_{\mathrm{dAt}}=$ Annual traffic that remains on other road(s) in year $\mathrm{t}$

\subsubsection{Benefits to induced traffic}

The benefit of a road improvement for induced traffic is the increase in the socio-economic user surplus. In Figure 2 this is represented by the area between the shadow demand curve and the new price line for the volume of induced traffic. Assuming a linear demand curve, this benefit can be determined as:

$$
\Delta \mathrm{U}_{\mathrm{It}}=1 / 2 \cdot\left(\mathrm{U}_{0 \mathrm{t}}-\mathrm{U}_{\mathrm{At}}\right) \cdot \mathrm{Q}_{\mathrm{It}}
$$

in which:

$\Delta \mathrm{U}_{\mathrm{It}}=$ Annual benefits to induced traffic in year $\mathrm{t}$

$\mathrm{U}_{0 \mathrm{t}} \quad=$ Shadow price per trip for the existing road

$\mathrm{U}_{\mathrm{At}}=$ Shadow price per trip for the improved road

$\mathrm{Q}_{\mathrm{Jt}} \quad=$ Annual induced traffic in year $\mathrm{t}$ 


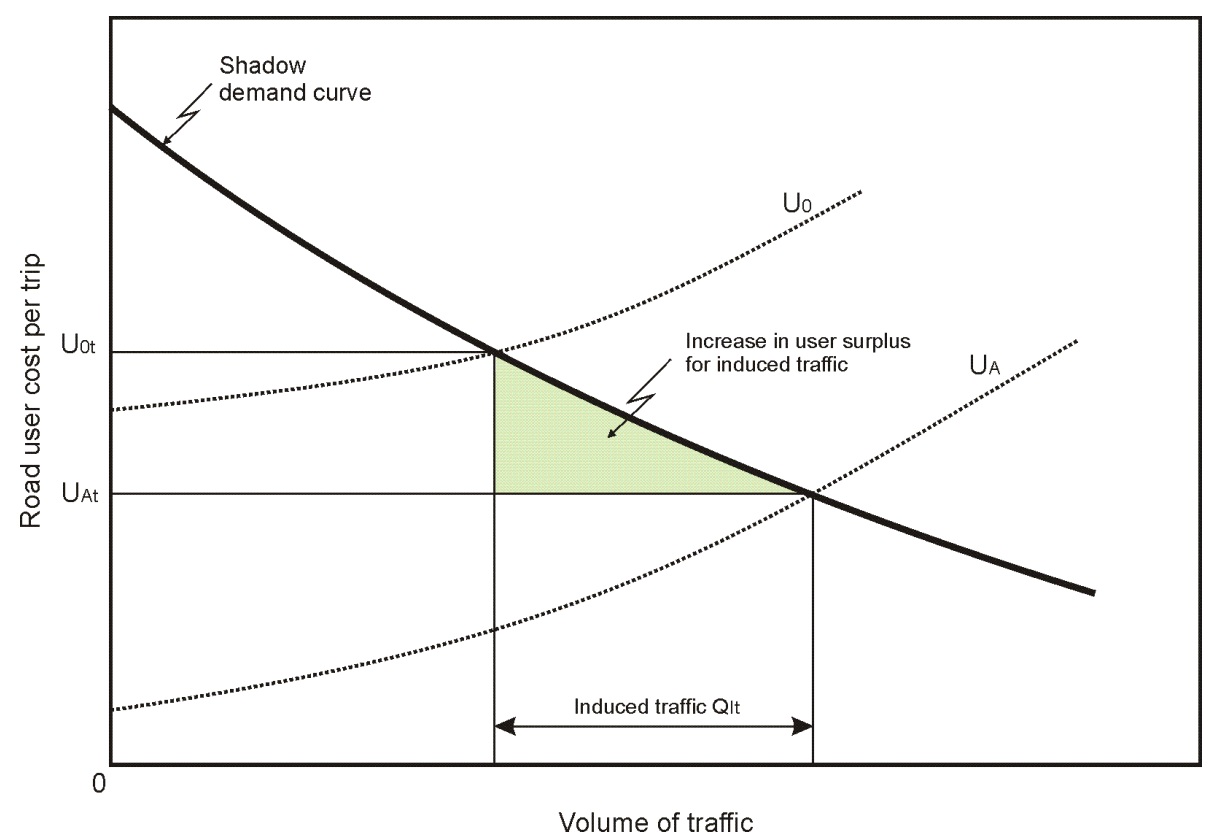

Figure 2: Road-user benefit of induced traffic

\subsubsection{Total users' benefit}

The total benefit that accrues to users in a year is the sum of the benefits for the different classes of traffic, as determined above:

$$
\Delta \mathrm{U}_{\mathrm{t}}=\Delta \mathrm{U}_{\mathrm{Nt}}+\Delta \mathrm{U}_{\mathrm{Dt}}+\Delta \mathrm{U}_{\mathrm{dDt}}+\Delta \mathrm{U}_{\mathrm{It}}
$$

in which:

$\Delta \mathrm{U}_{\mathrm{t}}=$ Total benefits accruing during year $\mathrm{t}$

$\Delta \mathrm{U}_{\mathrm{Nt}}=$ Annual benefits to normal traffic

$\Delta U_{D t}=$ Annual benefits to diverted traffic

$\Delta \mathrm{U}_{\mathrm{dDt}}=$ Annual benefits to traffic remaining on other road after diversion

$\Delta \mathrm{U}_{\mathrm{It}}=$ Annual benefits to induced traffic

\section{SOCIAL EQUITY IN ROAD CONSTRUCTION PROJECTS}

A compelling objection against SCBA is that its reliance on willingness to pay biases the method in favour of the existing distribution of income. Being based on allocative efficiency, its results tend to be prejudiced in favour of roads that serve high-income, rather than low-income, groups or regions.

The attainment of an economically efficient outcome is often construed as an allocation of resources that is so-called Pareto optimal. This is an allocation of resources that makes at least one person in a community better off without anyone else being made worse off. In reality, this is an elusive objective, and as far as the allocation of societal resources to road provision is concerned, it is an unachievable ideal. As a mitigating measure for the infeasibility of Pareto optimality, SCBA resorts to the underlying idea of potential compensation - i.e., those who gain can, in principle, compensate those who suffer, so that everybody can be better off. The conceivers of this idea were Kaldor [10] and Hicks [11]. However, the Kaldor-Hicks test can lead to inconsistencies when a project is large enough (1) to alter the relative prices of goods, and (2) to affect real income [12].

First, it could happen that, at prices without the project, the gainers are able to compensate the losers for the change; and with the project, at new prices, it may be possible for the losers to 'bribe' the winners to forego the change. Second, it could happen that, with the project, real income increases sufficiently to decrease the marginal utility of the additional income meaningfully enough so that, again, the winners can compensate the losers to accept the project, and the losers are able to compensate the winners to forego the project. Compensation is, however, not normally paid; therefore 
a government following allocative efficiency criteria could carry out a sequence of projects that benefit high-income groups at the expense of low-income ones. The net result would be to aggravate income inequality.

Apart from these two paradoxes that may (in theory) occur, there remains a problem even when compensation is paid: willingness to pay not only relies on preferences, but also on the ability to pay. In reality, reversal from a 'with' situation back to a 'without' situation is unlikely, which implies that the losers will have to be informed beforehand of how the 'with' situation will affect them. Given that the distribution of income without the project is not optimal, indigent losers in the population could lack the ability to compensate, even if they were willing to. Willingness to compensate ought, therefore, to be weighted.

The principles underlying such a weighting methodology are offered in the subsequent paragraphs; these will adjust the ranking priorities in favour of low-income groups by trading some allocative efficiency in favour of distributive efficiency in an attempt to reduce social inequality between different groups/regions. The proposed method does not replace the conventional SCBA methodology and cannot be used to determine whether a project is allocatively efficient. It is used to rearrange the relative preference of economically justified projects to mitigate societal inequity. The adjustment is therefore undertaken only for projects that have been demonstrated through SCBA to be economically efficient, and cannot be used to justify economically inefficient ones.

The creation and use of new and improved roads (especially access roads) and other public road transport facilities (e.g., passenger transport terminals and transfer facilities) can lead to a more equitable distribution of welfare and income. The fundamental point of departure is that additional income is relatively more valuable to lower-income groups than to higher-income ones. The users of public transport facilities and services, for example, are mostly transit-captive travellers, as they, more often than not, do not have the ability to pay for travel on alternative modes of transport; they are, by implication, the needier group in society.

Seeing that the appreciation of the marginal utility of income of lower-income groups is considerably higher than among more prosperous individuals, the net economic benefits that a transport project has for them should be weighted accordingly to reflect its social benefit. Seen in transport-economic terms, the inclusion of equity in the evaluation process is geared to creating equal accessibility and increased mobility for lower-income groups in terms of marginal utility. From a non-transport or general economic point of view, striving for greater equity is geared towards allotting potential economic activity and its returns to lower-income communities [13].

The method that is used for incorporating equity in SCBA is based on the application of weightings to the road-user benefits that are received by the various income groups. This weighting is aimed at making a project appear better than it would otherwise be, thus affecting its ranking and chances of selection for implementation.

One of the disadvantages of a weighting system is that it could be subjective and based on value judgements. However, the same applies to the decision not to use a weighting system at all, since giving equal weighting to all groups is just one weighting system among others, although it is the simplest to apply. In SCBA, the omission of all explicit weighting is associated with allocative efficiency and the acceptance of the prevailing income distribution; therefore a decision to apply the economic efficiency criterion is itself a value judgement [14]. The UK Treasury supports the weighting of the value of benefits with computed equity weightings, and declares that "where appraisers decide not to adjust explicitly for distributional impacts, they must provide a justification for this decision" [15].

Welfare distribution weightings can be based either on income or on consumer spending. Traditionally, the weightings have been based on per capita income, but there are reasons why they should rather be based on per capita consumer spending [16]:

(a) The relationship between income and utility attainment is not very clear, while per capita consumption expenditure provides a relatively good indication of this relationship. Individuals with the least income have to expend their disposable income mainly on life's necessities and basic need satisfaction, while individuals in the middle-income group also have the 
opportunity for precautionary expenditure, such as contributions towards pension, insurance, and medical funds; individuals who receive the highest income also have the opportunity for speculative expenditure such as investments in share schemes and lucrative profit opportunities.

(b) It will require a considerable amount of calculation and bold assumptions to deduce gains in personal utility from total income, as all transfer payments to and from individuals are not reported in total income statistics.

The welfare distribution weighting assigned to a road can be determined using the following generalised formula:

$$
\mathrm{W}_{\mathrm{R}}=\frac{\sum_{\mathrm{i}} \mathrm{P}_{\mathrm{i}}}{\sum_{\mathrm{i}} \mathrm{P}_{\mathrm{i}} / \mathrm{W}_{\mathrm{i}}}
$$

in which:

$W_{R}=$ Welfare distribution weighting for a road

$\mathrm{P}_{\mathrm{i}} \quad=$ Population of area $\mathrm{i}$ served by the road

$\mathrm{W}_{\mathrm{i}} \quad$ = Weighting applicable to area $\mathrm{i}$

The weighting applicable to area $i$ is determined using the following formula:

$$
\begin{array}{cc}
\mathrm{W}_{\mathrm{i}}=\mathrm{C}_{\mathrm{P}} / \mathrm{C}_{\mathrm{i}} & \text { for } \mathrm{C}_{\mathrm{i}}<\mathrm{C}_{\mathrm{p}} \\
\mathrm{W}_{\mathrm{i}}=1 & \text { Otherwise }
\end{array}
$$

in which:

$\mathrm{W}_{\mathrm{i}} \quad=$ Weighting applicable to area $\mathrm{i}$

$C_{p} \quad=$ Per capita consumer spending of the population

$\mathrm{Ci}=$ Per capita consumer spending in area $\mathrm{i}$

The above formulae may be used when data are available for the per capita spending for the different areas.

Since 2012, information about consumer expenditure in South Africa has been available for regions as small as municipal areas, and it is updated and published annually [17]. Because updated population estimates are available for the same areas, it has been possible since then to estimate per capita consumer spending sufficiently reliably for application in social evaluations.

The prescribed equity weightings are applied by multiplying the weightings by the user benefits (i.e., the sum of travel time, vehicle operating cost, and accident cost reductions) offered by the facility or service, and not by the external cost and road maintenance cost reductions. This is because the external costs and road maintenance costs fall on the whole of society, while project beneficiaries constitute the target group. The weightings are applied as follows to determine the user benefit of a project:

$$
\text { Weighted user benefit }=\text { User benefit } \cdot W_{R}
$$

The weighted user benefit component is then added to the savings in external and road maintenance cost components to determine the adjusted numerator value of the benefit/cost ratio used for prioritising or ranking the projects. The investment cost component, being the denominator value in the benefit/cost ratio, also remains unweighted because it represents government expenditure, and therefore funding by society as a whole.

\section{ECONOMIC IMPACT ANALYSIS}

The economic impacts of road supply are the effects a road project has on the economy of an area. Examples of such impacts may include changes in property values, business revenue, work opportunities, relative prices of goods, and real personal income. Economic impacts manifest as non-user consequences. For an economically justified road project, the net non-user consequences are always positive. However, these consequences are evaluated separately in an economic impact 
analysis, supplementary to an SCBA. Taking economic impacts into account in the SCBA would amount to (1) double counting and (2) an overestimation of the benefits of a project.

First, double counting: positive economic impacts are not included in an SCBA, since they are the consequence of savings in recurring costs resulting from a road improvement that have already been included in the SCBA.

Second, overestimation: positive non-user benefits do not involve savings as user benefits do, but represent a group of plus-factors or returns that are partly the consequence of investments in other sectors of the economy. Each type of economic activity that realises a positive net return has a producer/seller surplus with respect to the product it provides. A road's socio-economic user surplus is realised through mobility: it cannot borrow from, or lay claim to, non-road surpluses realised in other economic sectors, even in cases where the availability of the road is a prerequisite for the generation, development, and success of an activity in another economic sector. A new road alone is not sufficient for economic development: additional investment is a prerequisite for the realisation of general economic and community benefits. For example, a public road that opens up a fertile area for agricultural development will not be credited with the economic benefit of the agricultural returns in an SCBA: it will be regarded as a benefit of the agricultural investment through which it came into being [18].

\section{CONCLUSIONS}

The total cost of road infrastructure supply and use comprises both once-off and recurring costs. Once-off costs comprise the investment that society makes to implement a road facility. Collectively, the once-off costs represent the cost component in SCBA. Recurring costs are incurred continuously throughout the service life of a facility. Reductions of recurring costs with a proposed road, compared with the present situation without the proposed road, form the basis of determining the benefit component in SCBA.

The cost component includes the shadow price for materials and equipment used, labour, contractor operating costs, project management costs, overhead costs, and normal profit - in fact, the actual scarcity value of all inputs that are needed to create the facility and to link it to the existing road network and places to which it provides access, ready for use.

The benefit component is determined as the reduction in recurring costs, with and without the road improvement. These recurring costs are (1) the costs experienced by road users; (2) the external costs imposed on non-users; and (3) road maintenance costs.

Whenever project benefits are expressed relative to project costs, it is imperative that the cost and benefit components of different projects be determined in a consistent way. Should negative recurring cost savings, whenever they occur, be included in the cost component in the evaluation of certain projects rather than in the benefit one, the relative values indicated for such projects will be distorted.

Investment in road facilities is regarded as sunk; therefore a road has neither a residual value during its service life, nor a terminal value at the end of its service life. To account adequately for benefits realised, it is desirable that the analysis period should stretch over the entire service life of a facility. For reasons given earlier, the analysis period must not exceed 30 years.

Equity weighting is only applied when the project is economically efficient, and when the user benefit component within the project benefits is positive. Weighting cannot be used to justify economically inefficient projects - it is only used to rearrange the priorities of allocatively efficient projects.

The additional income stemming from (1) the multiplying effects of investment in road infrastructure, and (2) the acceleration and stimulation of industrial, commercial, or other incomebearing activities through the use of an economically beneficial facility, is not taken into account in the SCBA of the facility: it is dealt with separately in an economic impact analysis. 
The incorporation of (a) external costs imposed by road supply and use on non-road users, and (b) distributive efficiency to complement allocative efficiency criteria in SCBA, and the addition of (c) positive spill-over effects in an economic impact analysis supplementary to SCBA, render application of the Scitovsky [12] reversal test superfluous. The warning by Graaff [4] - that "[t]he implications for cost-benefit analysis are quite devastating if the Scitovsky reversal test is ignored" - is counteracted by the incorporation and addition of the three analyses discussed in this work.

\section{REFERENCES}

[1] Black, P. A., Calitz, E. \& Steenekamp, T. 2015. Public economics, 6th edition. Cape Town: Oxford University Press.

[2] Conningarth Economists. 2014. A manual for cost-benefit analysis in South Africa with specific reference to water resource development, 3rd edition. (WRC Report K8/1044/4). Pretoria: Water Research Commission.

[3] Winfrey, R. 1975. Consumer surplus does not apply to highway transportation economy. Transportation Research Record, 550.

[4] Graaff, J. de V. 1975. Cost-benefit analysis: A critical view. South African Journal of Economics, 43(2): 234-245.

[5] Brent, R. J. 2017. Advanced introduction to cost-benefit analysis. Cheltenham, England: Edward Elgar.

[6] Goodwin, P. B. 1974. Generalised time and the problem of equity in transport studies. Transportation, 3: 1-24.

[7] Button, K. J. 1993. Transport economics, 2nd edition. Cheltenham, England: Edward Elgar.

[8] Sinha, K. C. \& Labi, S. 2007. Transportation decision making: Principles of project evaluation and programming. Hoboken, NJ: John Wiley \& Sons.

[9] Pienaar, W. J. \& Bester, C. J. 2002. Modelling the non-monetary component of generalised travel costs for use in the cost-benefit analysis of bus transit facilities. Journal of the South African Institution of Civil Engineering, 44(1): 2-8.

[10] Kaldor, N. 1939. Welfare comparisons of economics and interpersonal comparisons of utility. Economic Journal, 49(195): 549-555.

[11] Hicks, J. R. 1939. The foundations of welfare economics. Economic Journal, 49(196): 696-712.

[12] Scitovsky, T. 1941. A note on welfare propositions in economics. Review of Economic Studies, 9: 77-88.

[13] Stopher, S. \& Stanley, J. 2014. Introduction to transport policy: A public policy view. Cheltenham, England: Edward Elgar.

[14] Snell, M. 1997. Cost-benefit analysis for engineers and planners. London: Thomas Telford.

[15] HM Treasury. 2012. The Green Book: Appraisal and evaluation in central government. Annexure 5: Distributional impacts. London: Treasury Stationery Office.

[16] Pienaar, W. J. 2014. The extension of cost-benefit analysis with social analysis in the planning of public road construction projects: Suggestion in support of the creation of a developmental state. Journal of Humanities, 54(4): 753-770.

[17] Quantec. 2017. EasyData. http://quanis1.easydata.co.za/TableViewer/dimView.aspx [Accessed 20 March 2017].

[18] Pienaar, W. J. 2016. Regional economic assessment of the planned De Beers Pass Road in South Africa. South African Journal of Industrial Engineering, 27(4): 182-192. 